\title{
Gamma-hydroxybutyrate abuse: pharmacology and poisoning and withdrawal management
}

\author{
Enrico Marinelli ${ }^{1}$, Renata Beck ${ }^{2}$, Antonio Malvasi ${ }^{3}$, Alfredo Fabrizio Lo Faro ${ }^{4}$, and Simona Zaami ${ }^{1}$ \\ ${ }^{1}$ Department of Anatomical, Histological, Forensic, and Orthopaedic Sciences, Sapienza University of Rome, Rome, Italy \\ 2 Department of Anaesthesia, Santa Maria Hospital, GVM Care \& Research, Bari, Italy \\ ${ }^{3}$ Department of Obstetrics and Gynaecology, Santa Maria Hospital, Bari, Italy \\ ${ }^{4}$ Section of Legal Medicine, Department of Excellence SBSP, University "Politecnica delle Marche” of Ancona, \\ Ancona, Italy
}

[Received in July 2019; Similarity Check in July 2019; Accepted in March 2020]

\begin{abstract}
Gamma-hydroxybutyrate (GHB) is a central nervous system depressant primarily used as a recreational drug of abuse, but also for the treatment of narcolepsy with cataplexy in adult patients and as an adjuvant for control of alcohol withdrawal syndrome. The main aim of this review is to summarise updated knowledge about GHB pharmacokinetics and pharmacodynamics, acute poisoning, and clinical features of GHB withdrawal syndrome, its diagnosis and medical treatment. The most common clinical signs and symptoms of acute poisoning include sleepiness to deep coma, bradycardia, hypotension, and respiratory failure. Therapy is essentially supportive and based on continuous monitoring of vital signs. GHB withdrawal syndrome shares patterns with other withdrawal syndromes such as alcohol withdrawal and is sometimes difficult to distinguish, especially if toxicological tests are GHB-negative or cannot be performed. There are no official detoxification protocols for GHB withdrawal syndrome, but its therapy is based on benzodiazepine. When benzodiazepine alone is not effective, it can be combined with barbiturates or antipsychotics. Information about abuse and distribution of GHB and its precursors/analogues among the general population is still limited. Their prompt identification is therefore crucial in conventional and non-conventional biological matrices, the latter in particular, to clarify all the issues around this complex molecule.
\end{abstract}

KEY WORDS: acute toxicity; GABA; gamma-aminobutyric acid; gamma-butyrolactone; 1,4-butanediol; GHB; pharmacodynamics; pharmacokinetics; withdrawal syndrome

Gamma-hydroxybutyrate (GHB) is an endogenous precursor of gamma-aminobutyric acid (GABA) and a central nervous system (CNS) depressant that has become notorious because of its abuse as a recreational drug in the form of a colourless, odourless liquid or white powder, tablet, and capsule under a number of street names ("Georgia Home Boy", "Juice", "Liquid Ecstasy", "Mils", "G", "Liquid X", "Liquid G", and "Fantasy") $(1,2)$. Under the commercial name Xyrem ${ }^{\circledR}$ it has been approved for the treatment of narcolepsy with cataplexy in adult patients in the US and Europe and under the commercial name Alcover ${ }^{\circledR}$ for the adjuvant treatment of alcohol dependence and withdrawal in Europe $(3,4)$.

GHB can easily be obtained from and even replaced by abusers with its synthetic precursors and analogues gammabutyrolactone (GBL) and 1,4-butanediol (1,4-BD), which are sold as solvents for industrial use and are therefore available for purchase (Figure 1) (5-7).

Corresponding author: Renata Beck, MD, Department of Anaesthesia, Santa Maria Hospital, GVM Care \& Research, Via Antonio de Ferraris 22, 70124 Bari, Italy, E-mail: beckrenata64@gmail.com
As the issue of GHB abuse has been widespread and is still raising a number of questions, we wanted to put together all the updated information we know about its pharmacokinetics and pharmacodynamics, acute poisoning, and the clinical features of GHB withdrawal syndrome, its diagnosis, and medical treatment. We also wanted to provide some background information about GHB history, trends, and context of (ab)use.

\section{LITERATURE SEARCH}

Our Pubmed and Scopus search included a wide date span from 1970 to 2019 with the following key words: "gamma-hydroxybutyrate", "gamma-butyrolactone", "1,4-butanediol", "GHB pharmacokinetics", and "GHB pharmacodynamics" alone or in combination with "GHB acute toxicity" and "GHB withdrawal syndrome". Besides these two databases, we also ran an Internet search that returned several books, non-indexed sources, and institutional websites. Of the 1,150 sources found, we excluded 305 duplicates. We then checked the remaining 845 to see if they matched our interests. Only 55 papers 
<smiles>O=C(O)CCCO</smiles>

GHB<smiles>O=C1CCCO1</smiles>

GBL<smiles>OCCCCO</smiles>
$1-4 \mathrm{BD}$
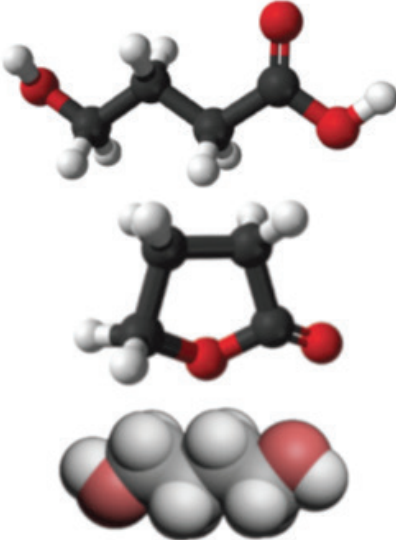

Figure 1 Chemical structures of GHB, GBL, and 1,4-BD

were considered appropriate for this review. All were written in English and were original research articles or reviews.

\section{GHB TRENDS, CONTEXT OF USE, AND FORENSIC TOXICOLOGY ISSUES}

Information about the trends of GHB use (including GHB analogous/precursors) among general population is limited, unlike with many other drugs (8). A recent report by the European Monitoring Centre for Drugs and Drug Addiction (EMCDDA) (9) says that the consumption of GHB and it analogues/precursors is generally low in Europe, save for particular contexts such as gay nightclubs (10-13). In this context of chemsex, GHB is frequently combined with synthetic cathinones (14) and other new psychoactive substances. It is a risky practice that has been reported for acute poisoning and even fatalities (15).

According to the Independent Drug Monitoring Unit (IDMU) report in 2003 (16), GHB use peaked between 1994 and 2002, and before 1990 very few people used it. GHB and its analogues/precursors are usually taken by young adults aged between 19 and 22, who had tried many other substances before $(16,17)$. Another US study $(18)$ reports a steady decline in GHB use from 2000 (the year in which GHB was declared illegal in the US) to 2008.

Even so, the issue of high mortality risk remains. GHB and its precursors/analogues are commonly detected in ante and post-mortem conventional and non-conventional biological matrices (mainly vitreous humour, hair, and nails) (19) by ultra-high performance liquid chromatography tandem mass spectrometry (UHPLC-MS/MS) and gas chromatography tandem mass spectrometry (GC-MS/MS) $(20,21)$. Cases of GHB adulteration have most often been reported in connection with chemsex $(22,23)$. Taking into account that this compound is both endogenous and exogenous, cut-offs play a key role in distinguishing between the two. In samples taken from living subjects these are $5 \mathrm{mg} / \mathrm{L}$ for blood and $10 \mathrm{mg} / \mathrm{L}$ for urine, whereas in post-mortem specimens they are $30 \mathrm{mg} / \mathrm{L}$ and $50 \mathrm{mg} / \mathrm{L}$ for peripheral and central blood, respectively and $10 \mathrm{mg} / \mathrm{L}$ for urine $(24,25)$.

\section{GHB HISTORY}

The first case of GHB synthesis dates back to 1874 and was reported by A. Zaytseff (26). Pioneering research on the effects of GHB in humans was led by Dr Laborit in the early sixties (25). In 1964, GHB was used as an anaesthetic, but has not taken root because of the considerable number of adverse effects. From the 1970s to 1980s, many cases of GHB abuse were reported among body builders for its alleged potential to increase growth hormones (27). Throughout the 1980s and 1990s, it gained notoriety as a stimulant of sexual performance, especially among regular nightclub goers $(1,2)$. Since the 1990s, GHB has gained more attention because of numerous cases of acute poisoning. In 2000, the US Drug Enforcement Agency (DEA) included GHB in Schedule I of drugs due to its potential for abuse and for physical and psychological dependence. In 2003, it was listed as a Class C drug in the UK Misuse of Drugs Act.

As a drug of abuse, GHB is under control in all the EU member states. However, it has also found application in the treatment of narcolepsy and less frequently as an adjuvant in the control of alcohol withdrawal syndromes and alcohol dependence $(2,28,29)$.

\section{GHB PHARMACODYNAMICS}

GHB is both GABA precursor and metabolite and a neuromodulator in the GABA system. Neurons that release GABA are mostly localised in the hippocampus, cortex, and amygdala, which is where $G$ protein-coupled receptors (GPCRs) $(30,31)$ are also located in pre and post-synaptic 
cells. After endogenous release, GHB binds to these receptors. However, to bind to the GABA-B receptor and exert its adverse effects, it must reach much higher levels obtained only with exogenous administration, because GHB is in fact a weak GABA-B agonist.

Its high affinity for receptors other than GABA-B has explained some of its pharmacological effects such as GHBinduced cataplexy in certain animal studies because of the involvement of $N$-methyl-D-aspartate (NMDA) receptors $(32,33)$.

GHB can also affect other neurotransmitter systems such as serotonergic and more notably dopaminergic. Some studies show that, after initial inhibition of dopamine release, GHB increases its production in a dose-dependent manner (33-36).

\section{GHB PHARMACOKINETICS}

\section{Absorption}

GHB shows good absorption after oral administration. In a study with eight male healthy volunteers receiving 12.5 , 25 , and $50 \mathrm{mg} / \mathrm{kg}$ of GHB (29) its time to reach maximum blood concentration $\left(\mathrm{T}_{\max }\right)$ ranged between 20 and $60 \mathrm{~min}$ and correlated with the dose $(25,30$, and $45 \mathrm{~min}$ in average, respectively). On the other hand, the maximum blood concentration achieved $\left(\mathrm{C}_{\max }\right)$ did not vary considering the received doses $(23,23$, and $20 \mu \mathrm{g} / \mathrm{mL}$ respectively), which suggests that GHB absorption is limited.

In another study with 12 healthy volunteers (six men and six women) (30) who received a single $25 \mathrm{mg} / \mathrm{kg}$ dose of GHB mean urine $\mathrm{T}_{\max }$ was $1 \mathrm{~h}$ and $\mathrm{C}_{\max } 67.6 \mu \mathrm{g} / \mathrm{mL}$, whereas blood $\mathrm{T}_{\max }$ was $24.6 \mathrm{~min}$ and $\mathrm{C}_{\max } 48.0 \mathrm{mg} / \mathrm{L}$.

\section{Distribution}

The mean volume of distribution varies from 192 to $741 \mathrm{~mL} / \mathrm{kg}$ in healthy volunteers and from 225.9 to $307 \mathrm{~mL} /$ $\mathrm{kg}$ in patients with narcolepsy and liver failure (37-39). No significant variations have been observed between the sexes or associated with concomitant food intake. GHB can cross the placental barrier. Its capacity of binding plasma proteins is reduced.

\section{Metabolism}

Over $90 \%$ of the administered dose of GHB undergoes hepatic metabolism by several enzymatic pathways and is closely related to GABA metabolism. The main route is oxidation by GHB dehydrogenase to produce succinic semialdehyde, which is further oxidised into succinic acid. Further metabolism via the Krebs cycle transforms it into carbon dioxide and water (Figure 2) (37-39).

\section{Excretion}

According to many animal studies, GHB excretion is non-linear. The same was observed in the eight volunteers after oral administration of a therapeutic GHB dose (29).

In the study with 12 healthy volunteers referred to above (30), urinary GHB concentration dropped below the endogenous cut-off of $5 \mathrm{mg} / \mathrm{L}$ in eleven of them six hours after administration, which suggests that only a small percentage (from 0.6 to $2.5 \%$ ) is excreted in urine (35-37).

\section{ACUTE POISONING WITH GHB}

\section{Clinical presentation}

Acute GHB poisoning can pose a medical challenge because it starts with unspecific symptoms shared by other acute poisonings with depressants.

In a retrospective study of 88 patients (61 men and 27 women, mean age 28 years) treated for acute GHB poisoning 59 ingested other substances as well, mainly alcohol (34 patients) and amphetamines ( 25 patients). In 53 patients the Glasgow Coma Scale (GCS) score was below 9. Of them, 25 patients had the GCS score 3 and 28 from 4 to 8 (39). The most common clinical signs were bradycardia (present in almost all patients with the GCS score under 8), frequently accompanied by hypotension, then hypothermia (21 patients), and acute respiratory acidosis. Tachycardia and hypertension were early clinical manifestations, usually occurring 15-30 min after ingestion (39).Almost all patients regained consciousness spontaneously within five hours of GHB ingestion.
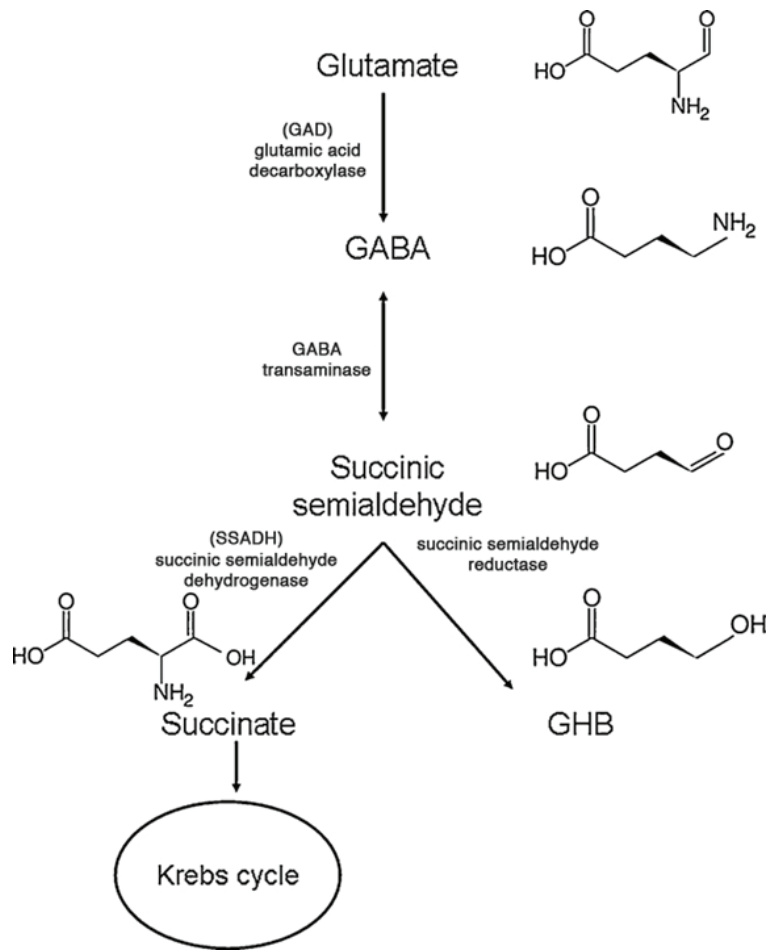

Figure 2 Synthesis of GABA from glutamate and metabolism into succinic semialdehyde or GHB (adapted from reference 37) 
There where GHB is taken with other substances, clinical presentation and management require more attention, because these other substances can "mask" some of the symptoms $(2,40)$.

Considering that GHB is a depressant acting on the central nervous system, the effects of acute poisoning can range from sleepiness to deep coma. They usually occur 15-50 minutes after ingestion and are short lived, which mainly depends on the dose. In most cases, neurological effects resolve within six hours. As a rule, management is supportive (29).

Table 1 shows neurological symptoms of acute GHB poisoning.

The most common respiratory manifestation is bradypnoea, which is often accompanied by type 2 respiratory failure.

The most common gastrointestinal symptoms are vomiting (present in 20-55 \% of cases, as reports vary in this respect), abdominal pain, and sialorrhoea (40-43).

\section{Determination and treatment}

To distinguish between exogenous and endogenous GHB, a threshold commonly used for samples taken from living patients is $10 \mathrm{mg} / \mathrm{L}$ in urine, and $5 \mathrm{mg} / \mathrm{mL}$ in blood. GHB is not stable in either and its concentration increases with time after sampling. In post-mortem blood, endogenous GHB concentrations can be much higher (see above) (44-47).

There are many methods for GHB detection in urine and blood. The most common is gas chromatography (GC) coupled with mass spectrometry (MS) or flame ionisation detection (FID). In addition, a number of liquid chromatography tandem mass spectrometric (LC-MS/MS) methods have recently been developed, which detect GHB after solid phase extraction (SPE) (48-50).

Therapy is essentially supportive and based on continuous monitoring of vital signs. Particular attention is paid to the cardiovascular and respiratory symptoms described earlier in the text.

Intubation is indicated in unconscious patients who are vomiting to prevent aspiration and choking.

Many substances such as (naloxone, flumazemil, or $\mathrm{GABA}_{\mathrm{B}}$ antagonists have been tried as potential antidotes, but there is no sufficient scientific evidence to support their routine application $(51-55)$

\section{GHB WITHDRAWAL SYNDROME}

\section{Clinical presentation}

The clinical presentation of GHB withdrawal syndrome is similar to other withdrawal syndromes, alcohol and benzodiazepine in particular. This is the reason why it can sometimes be very difficult to distinguish between them, especially if GHB tests are negative or could not be run (4, 60-63).

Considering the limited time of GHB action and its rapid elimination, signs and symptoms of GHB withdrawal syndrome soon become apparent, usually within $1-6 \mathrm{~h}$ after the last administration.

The withdrawal symptoms, however, can last for quite a while, 14 days or even more. They include anxiety, different degrees of depression, cognitive deficits, persistent insomnia $(56,57)$, tremor, and tachycardia, which is often accompanied by hypertension. Other common clinical manifestations include confusion, disorientation, and paranoia. They usually last between three and 21 days (58).

Most people with dependency have been taking GHB and/or its analogues/precursors for less than two years, and the first manifestations appear as soon as $8-13$ weeks into the use.

In a retrospective study (59) of eight patients with chronic GHB use, the first clinical manifestations of withdrawal appeared as quickly as $1-6 \mathrm{~h}$ after the administration of the last dose, and symptoms lasted between 5 and 15 days. Within $24 \mathrm{~h}$ from the last dose manifestations included severe anxiety and insomnia, moderate nausea, and vomiting. In the following five days, anxiety and insomnia continued, accompanied by delirium, confusion, and visual hallucinations. Seven to 15 days after the last dose, moderate anxiety, confusion, insomnia, and visual hallucinations persisted only episodically. Delirium was more frequent in patients who had been taking GHB every $30 \mathrm{~min}$ to $8 \mathrm{~h}$ than in those taking it every $1-24 \mathrm{~h}$.

\section{Management and therapy}

Case studies presented in medical literature provide general guidelines based on experience and common symptoms with other withdrawal syndromes, but there are no formal detoxification protocols for GHB or its analogues. Withdrawal therapy is based on benzodiazepine and when benzodiazepine alone is not effective against severe

Table 1 Neurological symptoms of acute GHB poisoning

\begin{tabular}{ccc}
\hline Very common symptoms & Common symptoms & Less common symptoms \\
Ataxia, disorientation, dizziness, & $\begin{array}{c}\text { Dysarthria, confusion, headache, } \\
\text { incoordination, euphoria, amnesia, } \\
\text { hypotonia, hyporeflexia, tremor, }\end{array}$ & $\begin{array}{c}\text { Bruxism, vertigo, disinhibition, } \\
\text { increased sexual arousal, delusions, } \\
\text { extrapyramidal side effects, dystonias, } \\
\text { somnolence, slurred speech, myosis }\end{array}$ \\
myoclonus, horizontal and vertical & athetosis, mydriasis \\
\hline
\end{tabular}




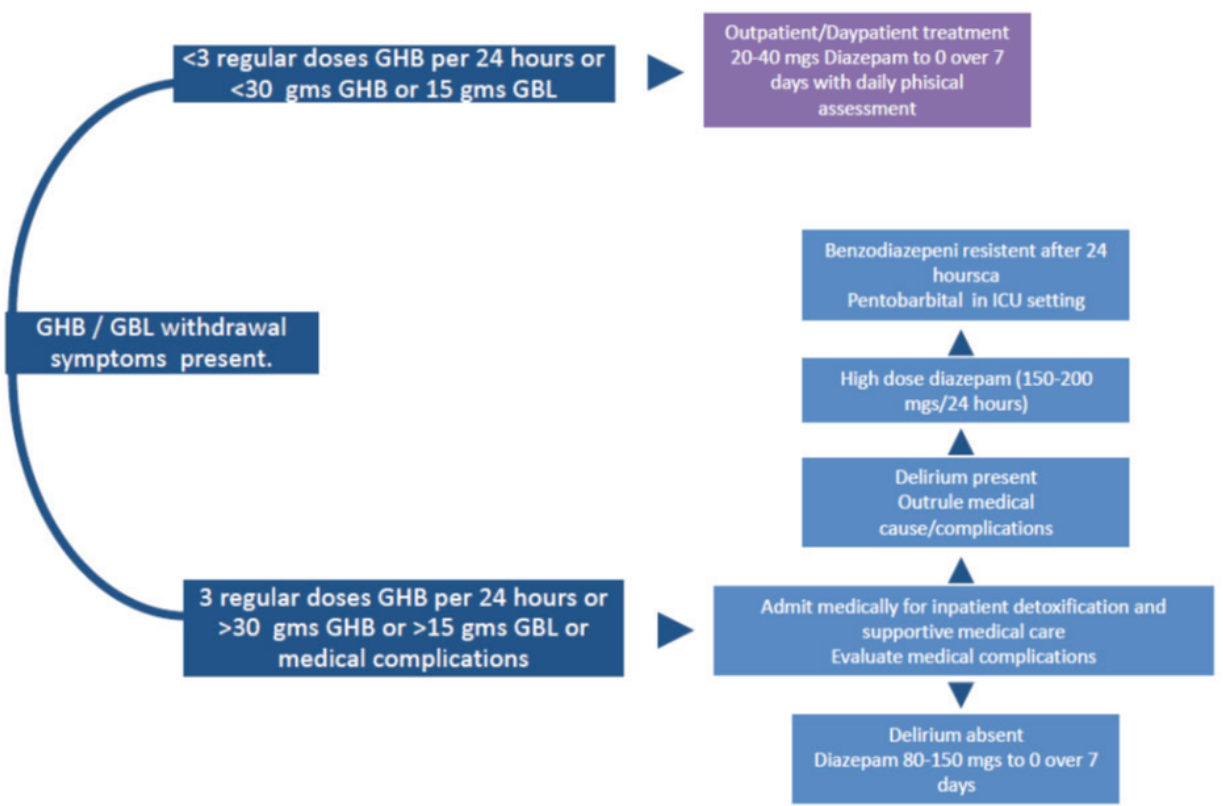

Figure 3 Algorithm for the management of the withdrawal syndrome in patients abusing GHB and its precursors/analogues (adapted from reference 63)

symptoms, it can be combined with barbiturates, baclofen, and antipsychotics $(4,60-63)$.

McDonough et al. (63) have come up with an algorithm (Figure 3) which takes into account the number of GHB/ analogue consumption in terms of amount and frequency per day. If a patient has been taking three or more doses or more than $30 \mathrm{~g}$ of GHB a day, the therapy should include diazepam (80-150 mg) for the first seven days. If the patient is in delirium, diazepam doses should be upped, and if the symptoms persists over 24 hours, adjuvant pentobarbital is recommended. If a patient has been taking less than three doses or $30 \mathrm{~g}$ of $\mathrm{GHB} /$ analogue a day, administration of lower doses of diazepam (20-40 mg) should suffice (63).

\section{NEW FRONTIERS IN GHB}

GHB is currently under legal control in a number of countries. Because of that, pushers and users have switched to two GHB precursors, GBL and 1,4-BD, which can still be legally purchased. GBL has become a growing public health issue because it is relatively cheap and easy to obtain due to many industrial uses (7). For this reason, the two prodrugs were also included in the UK Misuse of Drugs Act in 2009. Italy has also included GBL in its Table IV of the Narcotics Act (Presidential Decree 309/90) but not 1,4BD.

GBL for recreational purposes is usually taken in its liquid form orally. One millilitre of pure GBL contains about $1.6 \mathrm{~g}$ of GHB. As the purity of GBL diminishes so does the amount of GHB. GBL tastes like stale water and smells like burnt plastic, whereas GHB is odourless and slightly salty. Both are colourless (64).
After ingestion and absorption in the gastrointestinal tract GBL rapidly metabolises into GHB by lactonase enzymes in the blood. GBL-naïve users could have a delayed or weakened effect of GHB, whereas people who have already taken this drug will experience the normal full effects due to increased production of lactonase enzymes $(65,66)$.

GBL is more lipophilic, more quickly absorbed by the gastrointestinal tract, and more bioavailable than its active metabolite GHB. These pharmacokinetic properties make GBL more potent and faster than GHB, but its effects last less time (65-67).

\section{CONCLUSION}

Information about GHB/precursor/analogue use and their distribution among the general population is limited. What we know is that it is used alone or in combination with other substances such as sexual and cognitive enhancers, new psychoactive substances, and alcohol (22, $68,69)$. Their prompt identification is therefore crucial in conventional and non-conventional biological matrices, the latter in particular $(70,71)$ to clarify all the issues around this complex molecule.

\section{REFERENCES}

1. Schep LJ, Knudsen K, Slaughter RJ, Vale JA, Mégarbane B. The clinical toxicology of gamma-hydroxybutyrate, gammabutyrolactone and 1,4-butanediol. Clin Toxicol 2012;50:45870. doi: $10.3109 / 15563650.2012 .702218$ 
2. Carter LP, Pardi D, Gorsline J, Griffiths RR. Illicit gammahydroxybutyrate (GHB) and pharmaceutical sodium oxybate $\left(\right.$ Xyrem $\left.^{\circledR}\right)$ : Differences in characteristics and misuse. Drug Alcohol Depend 2009;104:1-10. doi: 10.1016/J. DRUGALCDEP.2009.04.012

3. Nicholson KL, Balster RL. GHB: a new and novel drug of abuse. Drug Alcohol Depend 2001;63:1-22. doi: 10.1016/ S0376-8716(00)00191-5

4. Busardò FP, Kyriakou C, Napoletano S, Marinelli E, Zaami S. Clinical applications of sodium oxybate (GHB): from narcolepsy to alcohol withdrawal syndrome. Eur Rev Med Pharmacol Sci 2015;19:4654-63. PMID: 26698265

5. Wood DM, Brailsford AD, Dargan PI. Acute toxicity and withdrawal syndromes related to gamma-hydroxybutyrate (GHB) and its analogues gamma-butyrolactone (GBL) and 1,4-butanediol (1,4-BD). Drug Test Anal 2011;3:417-25. doi: $10.1002 /$ dta.292

6. Rambourg-Schepens MO, Buffet M, Durak C, Mathieu-Nolf M. Gamma butyrolactone poisoning and its similarities to gamma hydroxybutyric acid: two case reports. Vet Hum Toxicol 1997;39:234-5. PMID: 9251175

7. Busardò FP, Gottardi M, Tini A, Minutillo A, Sirignano A, Marinelli E, Zaami S. Replacing GHB with GBL in recreational settings: a new trend in chemsex. Curr Drug Metab 2018;19:1080-5. doi: 10.2174/13892002196661809 25090834

8. Hibell B, Andersson B, Bjarnason T, Ahlström S, Balakireva O, Kokkevi A, Morgan M. The ESPAD report 2003 : alcohol and other drug use among students in 35 European countries. Stockholm: Swedish Council for Information on Alcohol and Other Drugs (CAN); 2004.

9. European Monitoring Centre for Drugs and Drug Addiction (EMCDDA). Report on the Risk Assessment of GHB in the Framework of the Joint Action on New Synthetic Drugs. Luxembourg: Office for Official Publications of the European Communities; 2002.

10. Knudsen K, Greter J, Verdicchio M. High mortality rates among GHB abusers in Western Sweden. Clin Toxicol 2008;46:187-92. doi: 10.1080/15563650701263633

11. Wood DM, Nicolaou M, Dargan PI. Epidemiology of Recreational Drug Toxicity in a Nightclub Environment. Subst Use Misuse 2009;44:1495-502. doi: $10.1080 / 10826080802543580$

12. Giorgetti R, Tagliabracci A, Schifano F, Zaami S, Marinelli E, Busardò FP. When "chems" meet sex: a rising phenomenon called "chemsex". Curr Neuropharmacol 2017;15:762-70. doi: 10.2174/1570159X15666161117151148

13. Marinelli S, Berretta P, Pacifici R, Del Rio A. Sex enhancers: challenges, threats and the need for targeted measures. Clin Ter 2019;170(3):e181-3. doi: 10.7417/CT.2019.2130

14. Zaami S, Giorgetti R, Pichini S, Pantano F, Marinelli E, Busardò FP. Synthetic cathinones related fatalities: an update. Eur Rev Med Pharmacol Sci 2018;22:268-74. doi: 10.26355/ eurrev 20180114129

15. Gentili S, Mortali C, Mastrobattista L, Berretta P, Zaami S. Determination of different recreational drugs in sweat by headspace solid-phase microextraction gas chromatography mass spectrometry (HS-SPME GC/MS): Application to drugged drivers. J Pharm Biomed Anal 2016;129:282-7. doi: 10.1016/j.jpba.2016.07.018
16. Gamma Hydroxy Butyrate Usage, Effects and UK Prices [displayed 10 July 2019]. Available at http://www.idmu. co.uk/oldsite/ghb.htm

17. McCambridge J, Mitcheson L, Winstock A, Hunt N. Fiveyear trends in patterns of drug use among people who use stimulants in dance contexts in the United Kingdom. Addiction 2005;100:1140-9. doi : 10.1111/j.1360-0443.2005.01127.x

18. Johnston LD, O'Malley PM, Bachman JG, Schulenberg JE. Monitoring the Future National Results on Adolescent Drug Use. Overview of Key Findings, 2011. Ann Arbor (MI): Institute for Social Research The University of Michigan; 2012.

19. Busardò FP, Bertol E, Vaiano F, Baglio G, Montana A, Barbera N, Zaami S, Romano G. Post mortem concentrations of endogenous gamma hydroxybutyric acid (GHB) and in vitro formation in stored blood and urine samples. Forensic Sci Int 2014;243:144-8. doi: 10.1016/j.forsciint.2014.07.019

20. Marchei E, Tini A, Pirani F, Lo Faro AF, Marinelli S. Is GHB-glucuronide useful as a biomarker for the exogenous use of GHB? Eur Rev Med Pharmacol Sci 2019;23:2311-3. doi: 10.26355/eurrev_201903_17369

21. Solimini R, Rotolo MC, Pellegrini M, Minutillo A, Pacifici R, Busardò FP, Zaami S. Adulteration practices of psychoactive illicit drugs: an updated review. Curr Pharm Biotechnol 2017;18:524-30. doi: 10.2174/1389201018666 170710184531

22. Pichini S, Marchei E, Pacifici R, Marinelli E, Busardò FP. Chemsex intoxication involving sildenafil as an adulterant of GHB. Drug Test Anal 2017;9:956-9. doi: 10.1002/ dta. 2054

23. Busardo FP, Kyriakou C. GHB in biological specimens: which cut-off levels should be taken into consideration in forensic toxicological investigation? Recent Pat Biotechnol 2014;8:206-14. doi: 10.2174/1872208309666150504143155

24. Beck R, Matanović SM, Zibar L. Gamma-hydroxybutyric acid, gamma-butyrolactone, and 1,4-butanediol addiction: a serious health threat. Arh Hig Rada Toksikol 2019;70:149 50. doi: 10.2478/aiht-2019-70-3295

25. Laborit H, Jouany JM, Gerard J, Fabiani F. [Summary of an experimental and clinical study on a metabolic substrate with inhibitory central action: sodium 4-hydroxybutyrate, in French]. Presse Med 1960;68:1867-9. PMID: 13758012

26. Zaytseff A. Über die Reduction des Succinylchlorids [On the reduction of succinyl chloride, in German]. Justus Liebigs Ann Chem 1874;171:258-90. doi:10.1002/jlac.18741710216

27. Britt GC, McCance-Katz EF. A brief overview of the clinical pharmacology of "club drugs". Subst Use Misuse 2005;40:1189-201. doi: 10.1081/JA-200066730

28. Takahara J, Yunoki S, Yakushiji W, Yamauchi J, Yamane Y, Ofuji T. Stimulatory effects of gamma-hydroxybutyric acid on growth hormone and prolactin release in humans. J Clin Endocrinol Metab 1977;44:1014-7. doi: 10.1210/jcem-445-1014

29. Busardò FP, Jones AW. Interpreting $\gamma$-hydroxybutyrate concentrations for clinical and forensic purposes. Clin Toxicol 2019;57:149-63. d o i : 10.1080/15563650.2018.1519194

30. Palatini P, Tedeschi L, Frison G, Padrini R, Zordan R, Orlando R, Gallimberti L, Gessa GL, Ferrara SD. Dose-dependent absorption and elimination of gamma-hydroxybutyric acid 
in healthy volunteers. Eur J Clin Pharmacol 1993;45:353-6. doi: $10.1007 / \mathrm{bf} 00265954$

31. Cuypers E, Flanagan RJ. The interpretation of hair analysis for drugs and drug metabolites. Clin Toxicol 2018;56:90-100. doi: $10.1080 / 15563650.2017 .1379603$

32. Pragst F, Balikova MA. State of the art in hair analysis for detection of drug and alcohol abuse. Clin Chim Acta 2006;370:17-49. doi: 10.1016/j.cca.2006.02.019

33. Ferrara SD, Tedeschi L, Frison G, Orlando R, Mazzo M, Zordan R, Padrini R, Palatini P. Effect of moderate or severe liver dysfunction on the pharmacokinetics of gammahydroxybutyric acid. Eur J Clin Pharmacol 1996;50:305-10. doi: $10.1007 / \mathrm{s} 002280050113$

34. Thai D, Dyer JE, Jacob P, Haller CA. Clinical pharmacology of 1,4-butanediol and gamma-hydroxybutyrate after oral 1,4-butanediol administration to healthy volunteers. Clin Pharmacol Ther 2007;81:178-84. doi: 10.1038/sj. clpt.6100037

35. Hoes MJ, Vree TB, Guelen PJ. Gamma-hydroxybutyric acid as hypnotic. Clinical and pharmacokinetic evaluation of gamma-hydroxybutyric acid as hypnotic in man. Encephale 1980;6:93-9. PMID: 7449723

36. Metcalf DR, Emde RN, Stripe JT. An EEG-behavioral study of sodium hydroxybutyrate in humans. Electroencephalogr Clin Neurophysiol 1966;20:506-12. doi: 10.1016/00134694(66)90107-6

37. van Amsterdam JGC, Brunt TM, McMaster MTB, Niesink RJM. Possible long-term effects of $\gamma$-hydroxybutyric acid (GHB) due to neurotoxicity and overdose. Neurosci Biobehav Rev 2012;36:1217-27. doi: 10.1016/j.neubiorev.2012.02.002

38. Morse BL, Morris ME. Toxicokinetics/toxicodynamics of $\gamma$-hydroxybutyrate-ethanol intoxication: Evaluation of potential treatment strategies. J Pharmacol Exp Ther 2013;346:504-13. doi: 10.1124/jpet.113.206250

39. Chin RL, Sporer KA, Cullison B, Dyer JE, Wu TD. Clinical course of gamma-hydroxybutyrate overdose. Ann Emerg Med 1998;31:716-22. doi: 10.1016/S0196-0644(98)70230-6

40. Ortmann LA, Jaeger MW, James LP, Schexnayder SM. Coma in a 20-month-old child from an ingestion of a toy containing 1,4-butanediol, a precursor of $\gamma$-hydroxybutyrate. Pediatr Emerg Care 2009;25:758-60. doi: 10.1097/ PEC.0b013e3181bec93b

41. Ingels M, Rangan C, Bellezzo J, Clark RF. Coma and respiratory depression following the ingestion of $\mathrm{GHB}$ and its precursors: three cases. J Emerg Med 2000;19:47-50. doi: 10.1016/s0736-4679(00)00188-8

42. Williams H, Taylor R, Roberts M. Gamma-hydroxybutyrate (GHB): a new drug of misuse. Ir Med J 1998;91:56-7. PMID 9617031

43. Chin MY, Kreutzer RA, Dyer JE. Acute poisoning from gamma-hydroxybutyrate in California. West J Med 1992;156:380-4. PMCID: PMC1003276

44. Elian AA. Determination of endogenous gammahydroxybutyric acid (GHB) levels in antemortem urine and blood. Forensic Sci Int 2002;128:120-2. doi: 10.1016/S03790738(02)00183-4

45. LeBeau MA, Christenson RH, Levine B, Darwin WD, Huestis MA. Intra- and interindividuai variations in urinary concentrations of endogenous gamma-hydroxybutyrate. J Anal Toxicol 2002;26:340-6. doi: 10.1093/jat/26.6.340

46. Elliott SP. Gamma hydroxybutyric acid (GHB) concentrations in humans and factors affecting endogenous production.
Forensic Sci Int 2003;133:9-16. doi: 10.1016/s03790738(03)00043-4

47. Yeatman DT, Reid K. A study of urinary endogenous gammahydroxybutyrate (GHB) levels. J Anal Toxicol 2003;27:40 2. doi: $10.1093 /$ jat $/ 27.1 .40$

48. Sørensen LK, Hasselstrøm JB. A hydrophilic interaction liquid chromatography electrospray tandem mass spectrometry method for the simultaneous determination of $\gamma$-hydroxybutyrate and its precursors in forensic whole blood. Forensic Sci Int 2012;222:352-9. doi: 10.1016/j. forsciint.2012.07.017

49. Elian AA, Hackett J. Anion exchange SPE and liquid chromatography-tandem mass spectrometry in GHB analysis. J Chromatogr B 2011;879:3752-8. doi: 10.1016/j. jchromb.2011.09.018

50. Dahl SR, Olsen KM, Strand DH. Determination of $\gamma$-hydroxybutyrate (GHB), $\beta$-hydroxybutyrate (BHB), pregabalin, 1,4-butane-diol (1,4BD) and $\gamma$-butyrolactone (GBL) in whole blood and urine samples by UPLC-MSMS. J Chromatogr B 2012;885-886:37-42. doi: 10.1016/j. jchromb.2011.12.009

51. Feigenbaum JJ, Howard SG. Naloxone reverses the inhibitory effect of $\gamma$-hydroxybutyrate on central DA release in vivo in awake animals: a microdialysis study. Neurosci Lett 1997;224:71-4. doi: 10.1016/s0304-3940(97)13470-x

52. Devoto P, Colombo G, Cappai F, Gessa GL. Naloxone antagonizes ethanol- but not $\alpha$-hydroxybutyrate-induced sleep in mice. Eur J Pharmacol 1994;252:321-4. doi: 10.1016/0014-2999(94)90179-1

53. Thomas G, Bonner S, Gascoigne A. Coma induced by abuse of gamma-hydroxybutyrate (GBH or liquid ecstasy): a case report. BMJ 1997;314:35-6. doi: 10.1136/bmj.314.7073.35

54. Lee DC, Satz WA, Dougherty T, Greene T. An investigation of flumazenil to antagonize gamma-hydroxybutyrate intoxication in a murine model. J Med Toxicol 2006;2:68-70. doi: 10.1007/bf03161174

55. Schmidt-Mutter C, Pain L, Sandner G, Gobaille S, Maitre M. The anxiolytic effect of $\gamma$-hydroxybutyrate in the elevated plus maze is reversed by the benzodiazepine receptor antagonist, flumazenil. Eur J Pharmacol 1998;342:21-7. doi: 10.1016/s0014-2999(97)01503-3

56. Mahr G, Bishop CL, Orringer DJ. Prolonged withdrawal from extreme gamma-hydroxybutyrate (GHB) abuse. Psychosomatics 2001;42:439-40. doi: 10.1176/appi. psy.42.5.439

57. van Noorden MS, van Dongen LCAM, Zitman FG, Vergouwen TA. Gamma-hydroxybutyrate withdrawal syndrome: dangerous but not well-known. Gen Hosp Psychiatry 2009;31:394-6. doi: 10.1016/j. genhosppsych.2008.11.001

58. Miglani JS, Kim KY, Chahil R. Gamma-hydroxy butyrate withdrawal delirium: a case report. Gen Hosp Psychiatry 2000;22:213-5. doi: 10.1016/s0163-8343(00)00071-2

59. Hutto B, Fairchild A, Bright R. $\gamma$-Hydroxybutyrate withdrawal and chloral hydrate. Am J Psychiatry 2000;157:1706. doi: 10.1176/appi.ajp.157.10.1706

60. Craig K, Gomez HF, McManus JL, Bania TC. Severe gammahydroxybutyrate withdrawal: a case report and literature review. J Emerg Med 2000;18:65-70. doi: 10.1016/s07364679(99)00163-8 
61. Gonzalez A, Nutt DJ. Gamma hydroxy butyrate abuse and dependency. J Psychopharmacol 2005;19:195-204. doi: 10.1177/0269881105049041

62. Hernandez M, McDaniel CH, Costanza CD, Hernandez OJ. GHB-induced delirium: a case report and review of the literature of gamma hydroxybutyric acid. Am J Drug Alcohol Abuse 1998;24:179-83. doi: 10.3109/00952999809001706

63. McDonough M, Kennedy N, Glasper A, Bearn J. Clinical features and management of gamma-hydroxybutyrate (GHB) withdrawal: a review. Drug Alcohol Depend 2004;75:3-9. doi: 10.1016/j.drugalcdep.2004.01.012

64. World Health Organization (WHO). $\gamma$-Butyrolactone (GBL). Who Expert Committee on Drug Dependence. WHO Technical Report Series 973. Geneva: WHO; 2012. p. 14-5.

65. Koek W, Mercer SL, Coop A. Cataleptic effects of $\gamma$-hydroxybutyrate (GHB), its precursor $\gamma$-butyrolactone $(\mathrm{GBL})$, and $\mathrm{GABA}_{\mathrm{B}}$ receptor agonists in mice: Differential antagonism by the $\mathrm{GABA}_{\mathrm{B}}$ receptor antagonist CGP35348. Psychopharmacology (Berl) 2007;192:407-14. doi: 10.1007/ s00213-007-0718-y

66. Carai MAM, Lobina C, Maccioni P, Cabras C, Colombo G, Gessa GL. $\gamma$-Aminobutyric $\operatorname{acid}_{B}\left(\mathrm{GABA}_{\mathrm{B}}\right)$-receptor mediation of different in vivo effects of $\gamma$-butyrolactone. J Pharmacol Sci 2008;106:199-207. doi: 10.1254/jphs. FP0071487
67. Goodwin AK, Brown PR, Jansen EEW, Jakobs C, Gibson KM, Weerts EM. Behavioral effects and pharmacokinetics of gamma-hydroxybutyrate (GHB) precursors gammabutyrolactone (GBL) and 1,4-butanediol (1,4-BD) in baboons. Psychopharmacology (Berl) 2009;204:465-76. doi: 10.1007/s00213-009-1477-8

68. Busardò FP, Pichini S, Zaami S, Pacifici R, Kintz P. Hair testing of GHB: An everlasting issue in forensic toxicology. Clin Chem Lab Med 2018;56:198-208. doi: 10.1515/cclm2017-0397

69. Busardò FP, Kyriakou C, Cipolloni L, Zaami S, Frati P. From Clinical Application to Cognitive Enhancement: The Example of Methylphenidate. Curr Neuropharmacol. 2016;14:17-27. doi: 10.2174/1570159x13666150407225902

70. Kyriakou C, Pellegrini M, García-Algar O, Marinelli E, Zaami $\mathrm{S}$. Recent trends in analytical methods to determine new psychoactive substances in hair. Curr Neuropharmacol 2016;15:663-81. doi: 10.2174/1570159x15666161111112545

71. Dornbierer DA, Kometer M, von Rotz R, Studerus E, Gertsch J, Salomé Gachet M, Vollenweider FX, Seifritza E, Bosch OG, Quednow BB. Effects of gamma-hydroxybutyrate on neurophysiological correlates of performance and conflict monitoring. European Neuropsychopharmacology 2019;29:539-48. doi: 10.1016/j.euroneuro.2019.02.004

\section{Zloporaba gama-hidroksibutirata - farmakologija, trovanje i liječenje ovisnosti}

Gama-hidroksibutirat (GHB) depresiv je središnjega živčanog sustava koji se ponajviše zlorabi kao rekreativna droga, ali se primjenjuje i za liječenje narkolepsije s katapleksijom u odraslih bolesnika te kao pomoćni lijek u kontroli sindroma odvikavanja od alkohola. Ljudi i endogeno proizvode GHB, budući da je on prekursor gama-aminomaslačne kiseline (GABA), jednoga od glavnih neurotransmitera s inhibicijskim učinkom na živčani sustav. GHB ima ulogu neuromodulatora u GABA sustavu i uglavnom djeluje preko GABA receptora. Za zloporabu se čestu kupuju GBH prekursori/analozi gama-butirolakton (GBL) i 1,4-butanediol (1,4-BD) u obliku otapala namijenjenih legalnoj industrijskoj uporabi. Oni, međutim, nisu endogeni. Glavni je cilj ovoga preglednog rada bio sažeti najnovije spoznaje o farmakokinetici $i$ farmakodinamici GHB-a, akutnom trovanju i o kliničkim značajkama sindroma odvikavanja od GHB-a, njegovoj dijagnozi i liječenju. Akutno je trovanje GHB-om donekle i dijagnostički izazov jer su znakovi i simptomi uobičajeni i za depresive središnjega živčanog sustava. Najčešći su klinički znakovi akutnoga trovanja pospanost (sve do duboke kome), bradikardija i hipotenzija te respiratorno zatajenje. Liječenje je u osnovi potporno, uz stalno praćenje vitalnih znakova. Sindrom odvikavanja od GHB-a dijeli značajke s drugim sindromima odvikavanja (npr. od alkohola ili benzodiazepina). Ponekad ih je vrlo teško razlikovati, ponajviše kada su testovi na GHB negativni ili nije moguće napraviti toksikološku analizu. Ne postoje službeni protokoli za detoksikaciju od GHB-a ili njegovih prekursora/analoga. Liječenje se temelji na primjeni benzodiazepina te, ovisno o težini simptoma, sekundarno barbituratima ili antipsihoticima.

KLJUČNE RIJEČI: akutna toksičnost; GABA; gama-aminomaslačna kiselina; gama-butirolakton; 1,4-butanediol; GHB; farmakodinamika; farmakokinetika; sindrom odvikavanja 